\title{
The effect of rearing temperature in larval development of pejerrey, Odontesthes bonariensis - Morphological indicators of development
}

\author{
Tomás Chalde ${ }^{1}$, Daniel A. Fernández ${ }^{2}$, Víctor E. Cussac ${ }^{3}$ and Gustavo M. Somoza ${ }^{1}$
}

It is well known that in pejerrey water temperature not only affects growth rates but also directs the sexual differentiation process. This fact rise the question of how different the development of pejerrey larvae of the same age is when reared at different temperatures. A description of developmental stages for the embryonic and larval periods of the pejerrey, Odontesthes bonariensis, and the influence of rearing temperature on larval development are presented. Then, larval development was studied at three rearing temperatures, and changes in general morphology, fin morphology, and caudal fin structure have been taken into consideration within the thermal range involved in the temperature sex determination of this species. Fin fold reabsorption, caudal fin formation, and body shape were selected to follow the events leading to the acquisition of the juvenile morphology. The juvenile phenotype was defined when the fin fold was reabsorpted and the caudal fin acquired its definitive homocercal structure. The moment at which the juvenile phenotype was achieved, was evaluated in relation to larval age, size and, shape. The size resulted as the best indicator of development in pejerrey.

A temperatura da água não afeta apenas as taxas de crescimento no peixe-rei, mas também direciona o processo de diferenciação sexual. Este fato levanta o questionamento de quão diferente é o desenvolvimento de larvas do peixe-rei da mesma idade quando criadas em temperaturas diferentes. Este trabalho teve como objetivo apresentar uma descrição do de desenvolvimento de embriões e larvas do peixe-rei, Odontesthes bonariensis, e a influência da temperatura de criação no desenvolvimento das larvas. Neste trabalho, o desenvolvimento das larvas foi estudado em três temperaturas diferentes de cultivo. Foram consideradas as alterações ocorridas na morfologia geral, assim como na morfologia e na estrutura da nadadeira caudal dentro da variação termal da temperatura de determinação sexual desta espécie. A taxa de reabsorção da membrana embrionária, a formação da cauda e o formato do corpo foram selecionados para acompanhar os eventos que levam à aquisição da morfologia juvenil. O fenótipo juvenil foi definido quando a nadadeira caudal foi reabsorvida e a cauda adquiriu a estrutura homocerca. $\mathrm{O}$ momento no qual o fenótipo juvenil foi atingido, foi avaliado quanto à idade, tamanho e formato da larva, sendo que o tamanho resultou no melhor indicador do desenvolvimento do peixe-rei.

Key words: Atherinopsidae, Fin fold, Larvae, Sexual determination.

\section{Introduction}

The early-life history of teleost fish includes a series of morphological, physiological, and ecological changes (Berlinsky et al., 2004; Al Hazzaa \& Hussein, 2007; Fujimura \& Okada, 2007; Murphy et al., 2007; Kawakami et al., 2008). In bony fish species characterized by an indirect development, three main consecutive periods can be recognized: embryo, larva, and juvenile (Youson, 1988, 2003). After hatching, the absorption of the yolk sac resources continues without exogenous feeding for a variable lapse depending on the species (Webb, 1999). Some authors propose the change from endogenous to exogenous feeding as the event indicating the transition from embryos to larvae (Balon, 1990). Nevertheless, other authors propose different events to define this moment: hatching, in the view of Blaxter (1988). In the same way, complete fin ray development (Kawakami et al., 2008), the mouth shift from an upper to lower position (Gozlan et al., 1999), or the change in the use of the habitat (Balon, 1999), have been taken as indicators of larval-juvenile transition (metamorphosis) in different fish species. The lack of agreement in the use of the word larvae (Balon, 2001; Blaxter, 1988; Kováè \& Copp, 1999; Hensel, 1999; McElman \& Balon, 1979) has impaired but only in part, the comprehension of the ecological and physiological

${ }^{1}$ Laboratorio de Ictiofisiología y Acuicultura. Instituto de Investigaciones Biotecnológicas, Instituto Tecnológico de Chascomús (CONICETUNSAM), Chascomús, Argentina.somoza@intech.gov.ar (GMS)

${ }^{2}$ Laboratorio de Ecofisiología. Centro Austral de Investigaciones Científicas (CONICET), Ushuaia, Argentina.

${ }^{3}$ Laboratorio de Ictiología y Acuicultura Experimental. Instituto de Investigaciones en Biodiversidad y Medio Ambiente (CONICETUNCOMAHUE), Bariloche, Argentina. 
significance of this period (Copp et al., 1999). Despite development has a stronger correlation with size than with age (Fuiman et al., 1998; Adriaens \& Verraes, 2002; Sæle \& Pittman, 2010), the last is still used as an indicator of development, i.e. the larval-juvenile transition.

Water temperature is known to be the most important environmental factor influencing fish development (Blaxter, 1992; Chambers \& Leggett, 1987). A close relationship between temperature and developmental rates has been reported in many fish species (Pepin, 1991; Martell et al., 2005; López-Olmeda \& Sánchez-Vázquez, 2010).

In the pejerrey Odontesthes bonariensis, water temperature not only affects growth rates but also directs the sexual differentiation process (Strüssmann \& Patiño, 1995; Ito et al., 2005). This species presents a strong temperature sex determination (TSD), a form of environmental sex determination (ESD) where $100 \%$ female or male populations can be obtained simply by controlling water temperature (Strüssmann et al., 1996a). In pejerrey, the critical or temperature-sensitive period occurs from the first to the fifth week after hatching, depending on temperature. Pejerrey larvae reared from hatching at $13-19^{\circ} \mathrm{C}$ produced $100 \%$ females, at $29^{\circ} \mathrm{C} 100 \%$ males, and mixed sex proportions at intermediate temperatures, $24-25^{\circ} \mathrm{C}$ (Strüssmann et al., 1996b, 1997; Karube et al., 2007; Fernandino et al., 2008a). Sex differentiation is also accelerated by rearing temperature; the ovarian differentiation occurs before at $24^{\circ} \mathrm{C}$ than at $17^{\circ} \mathrm{C}$, whereas testis development takes place before at $29^{\circ} \mathrm{C}$ than at $24^{\circ} \mathrm{C}$ (Ito et al., 2005; Fernandino et al., 2008b). Also, germ cell degeneration usually became histologically recognizable after one to two weeks of exposure to temperatures higher than $29^{\circ} \mathrm{C}$ and became more severe with increasing duration of exposure (see Strüssmann et al., 2010).

The above-mentioned concepts arise the question of how different is the development of pejerrey larvae of the same age reared at different temperatures. Therefore, the aims of the present study were: a) to provide a brief description of the embryo period and a morphological and quantitative description of the larval development of $O$. bonariensis to complete previous information on this species (Minoprio, 1944; Muñiz Saavedra \& Piacentino, 1991); b) to describe the effects of the thermal range involved in TSD on larval development, and c) to generate an operative definition of pejerrey larva and juvenile.

\section{Material and Methods}

\section{Fertilization and incubation}

For the characterization of embryo development, the eggs were obtained from six years old pejerrey brood-stock at the "Instituto Tecnológico de Chascomús" aquatic facilities in spring, by controlled fertilization. Before manipulation, the fish were anesthetized by immersion in a $100 \mathrm{ppm}$ benzocaine solution for five minutes approximately. Fertilization time was taken as the moment when the oocytes took contact with the milt. The fertilized oocytes were then incubated at $19 \pm 0.5^{\circ} \mathrm{C}$ in a flow-through water $(4-5 \mathrm{NaCl} \mathrm{g} / \mathrm{L})$ incubator.

\section{Larval rearing}

For the characterization of larval development, fertilized eggs were obtained from spontaneous spawning events of the same captive-reared brood-stock. Newly spawned eggs were collected early in the morning and incubated in the previously described conditions. After hatching, three groups of 1,500 larvae each one were kept in 1301 fiberglass tanks with flow-through water under 12L:12D light cycle, and salinity $15 \mathrm{~g} / \mathrm{L}$. The tanks were kept at three different temperatures: female producing temperature $\left(\mathrm{FPT}=17^{\circ} \mathrm{C}\right)$, mixed-sex producing temperature $\left(\mathrm{MixPT}=24^{\circ} \mathrm{C}\right)$ or male producing temperature $\left(\mathrm{MPT}=29^{\circ} \mathrm{C}\right.$ ) according to Strüssmann et al. (1997). Water temperature in the tanks was recorded with data-loggers and maintained with heaters with electronic control.

The larvae were feed daily at satiation with Artemia nauplii until day 42, and then supplied with artificial fish food (Shullet $\AA$, Argentina).

\section{Embryonic development}

The embryo development was registered using a Nikon SMZ800 stereomicroscope connected to a digital camera. In order to facilitate the correct orientation of the embryos, they were set into a Petri dish full of a $0.01 \%$ agar solution. The time at which each developmental stage took place was considered as the moment where at least five out of ten embryos sampled from the same pool presented the same characters.

\section{Larval development}

The morphological changes occurring during larval development stages were only described from larvae reared at MixPT. After hatching, ten larvae from each tank were photographed once a week with a digital camera using the same stereomicroscope. To study fin development, ossification of caudal fin rays, and the formation of the first and second dorsal and anal fin rays, Alizarin Red and Alcian Blue staining were carried out using a protocol adapted from Potthoff (1984). The number of caudal fin segments was counted on digital images on a dark field.

To describe the effects of temperatures on larval development the following morphometrics measurements (orbital diameter, inter-orbital distance, head length, pectoral fin length, head width, pre-orbital distance, post-orbital distance, head depth, caudal peduncle depth, body depth, anal distance, total length, and standard length), were taken from larvae reared at MPT, MixPT and FPT and measured to the nearest $0.001 \mathrm{~mm}$ using digital images and the Image-pro plus 4.0 software.

Body weight (BW), total length (TL), and the mentioned morphometric measurements were transformed to decimal logarithms in order to obtain linear relationships. Unstandardized residuals were obtained from the regression of morphometric measurements with $\log \mathrm{TL}$ in order to eliminate the effect of size on the body shape analysis.

The Condition Factor $\left(\mathrm{CF}=1000 \times \mathrm{BW}(\mathrm{mg}) \times \mathrm{SL}(\mathrm{mm})^{-3}\right)$ was used as an indicator of body shape. The effects of temperature (as a fixed factor) on TL, BW, and CF were analyzed using ANCOVA, considering time or TL as co-variables. Multivariate 
analysis of body shape (see morphometric measurements) was conducted using Discriminant Analysis (DA) in order to show the effects of developmental temperatures.

\section{Results}

\section{Embryonic development}

Just spawned oocytes were yellow-green, surrounded by a transparent zona radiata (sensu Kunz, 2004). The oocyte diameter before fertilization was around $1.68 \pm 0.01 \mathrm{~mm}$ (mean \pm standard error, $\mathrm{N}=84$ ) and most of the volume was occupied by the yolk.
At that moment the oocytes presented a series of oil droplets $(40.7 \pm 1.2 ; \mathrm{N}=41)$ with sizes ranging from 30 to $250 \mu \mathrm{m}$. They also presented some, among 3-10, adherent filaments per egg.

Just after fertilization the perivitelline space $(68 \pm 12 \mu \mathrm{m}$; $\mathrm{N}=81$ ) was clearly defined, and 1.5 hours post fertilization (hpf) the cytoplasm streamed towards the animal pole forming a cap-shaped bulge, the blastodisc (Fig. 1A).

The first cleavage occurred $2 \mathrm{hpf}$ originating two rounded cells (Fig. 1B). The cells kept their rounded shape until the fourth cleavage that produced 16 blastomeres arranged in 12 peripheral and 4 central cells. At 64 blastomeres, the symmetry
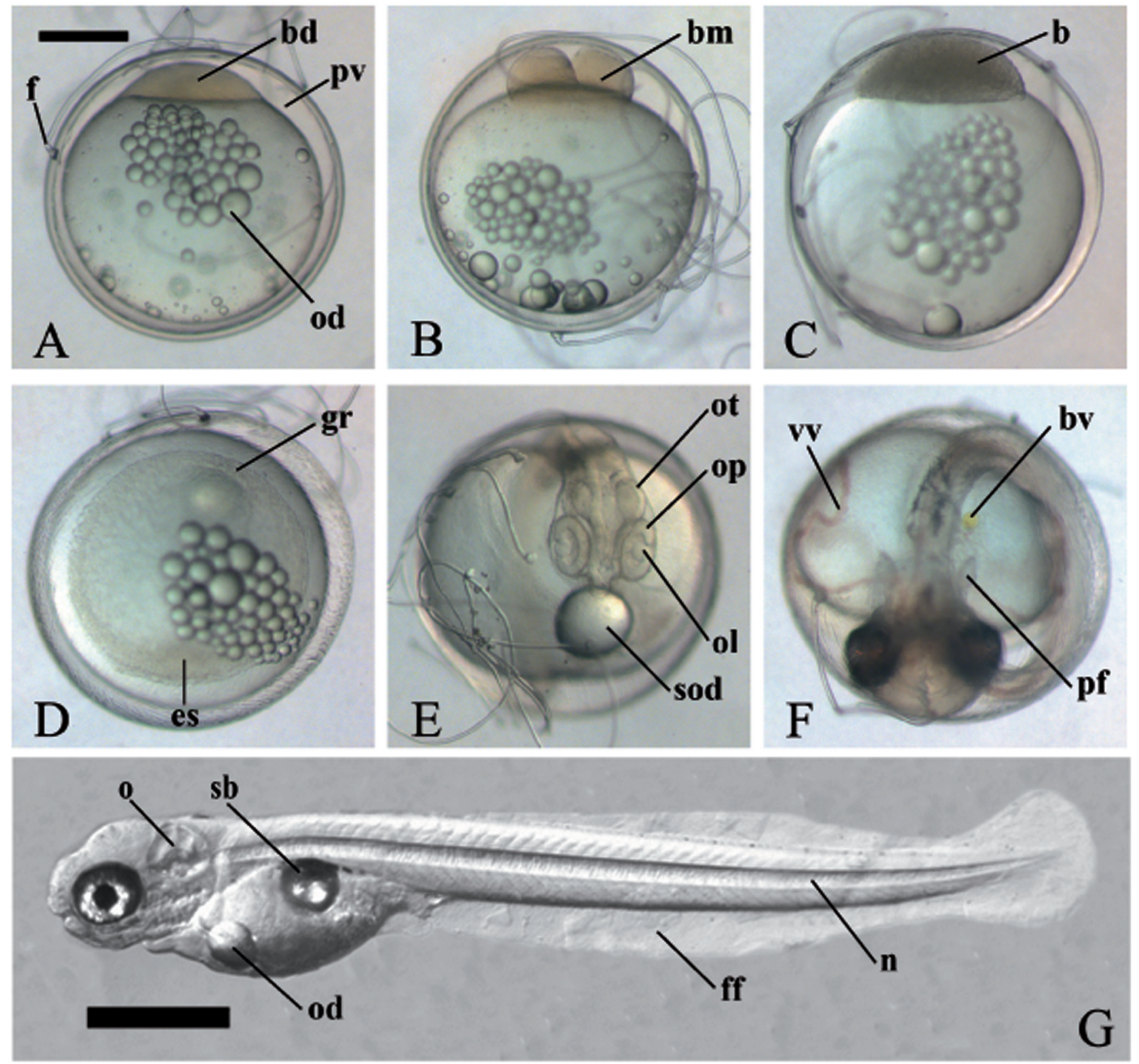

Fig. 1. Embryonic stages of pejerrey. A) One cell stage: bd, blastodisc; f, adherent filaments; od, oil droplets; pv, perivitelline space; B) Two cells stage: bm, blastomeres; C) Blastula stage: b, blastula; D) Animal pole view at 25\% epiboly stage, es, embryonic shield; gr, germinal ring; E) Vitelline veins stage: ol, ocular lenses; op, optic capsule, ot; otic capsules; sod, single oil drop; F) Pectorals fins stage: bv, bile vesicle; pf, pectoral fins; vv, vitelline veins. G) Hatching: n, notochord; o, otoliths; sb, swim bladder; sod, single oil droplet. A-F) bar $=0.5 \mathrm{~mm} ; \mathbf{G})$ bar $=1 \mathrm{~mm}$. 
Table 1. Embryonic development. Stages, hours post fertilization (HPF) and characteristics.

\begin{tabular}{llcl}
\hline & Stage & HPF & Characteristics \\
\hline Zygote & Just fertilized egg & 0 & Cortical cytoplasm equally distributed. \\
& Blastodisc & 1.5 & Cortical cytoplasm concentrated on the animal pole. \\
\hline Cleavage & 2 Cells & 2 & First cleavage. \\
& 4 Cells & 3 & Second cleavage. $2 \times 2$ blastomeric array. \\
& 8 Cells & 4 & Third cleavage. $2 \times 4$ blastomeric array. \\
& 16 Cells & 5 & Fourth cleavage. 4 central and 12 peripheral blastomeres. \\
& 32 Cells & 6.5 & Fifth cleavage. $4 x 8$ blastomeric array. \\
64 Cells & 7.5 & First equatorial cleavage. \\
Blastula & 8.5 & Blastoderm dome-shaped with several cellular layers. \\
\hline Gastrulation & 25\% Epiboly & 26 & The blastoderm margin expands $1 / 4$ over the yolk. The germ ring and embryonic shield are formed. \\
& 50\% Epiboly & 29 & Beginning of the embryonic axis formation on the embryonic shield. \\
& 90\% Epiboly & 38 & The notochord rudiment starts to be visible. \\
\hline Neurulation & Optic primordial & 47 & The somitogenesis begins. The eye primordium and Kupffer's vesicle can be distinguished. \\
& Otic primordial & 52 & The otic capsule is visible. \\
& Ocular lenses & 63 & The number of somites increases and the ocular lenses is visible. \\
Oil drop & 95 & The oil droplets coalesce into a single drop. \\
Vitelline veins & 97 & The vitelline veins, optic and otic capsules are clearly distinguished. \\
& Heart & 131 & The heart is visible and blood flow can be clearly seen. First movements of the tail. \\
Ocular pigments & 147 & The olfactory bulbs, telencephalon and the optic cups with pigmented retina are distinguished. \\
& Pectoral fins & 170 & The pectoral fins and bile vesicle can be observed. The body pigmentation begins. \\
Swim bladder & 220 & Cephalic melanophores and an inflated swim bladder can be observed. \\
Hatching & 270 & \\
\hline
\end{tabular}

of the cleavage planes was difficult to observe. Until the midblastula transition, the cleavage rate was approximately of 1 division per 1 to $1.5 \mathrm{~h}$. Finally, 8.5 hpf a "ball-like" blastoderm, the blastula, was formed (Fig. 1C).

At $26 \mathrm{hpf}$, the blastoderm cells produced $25 \%$ epiboly and the germinal ring and the embryonic shield were clearly visible (Fig. 1D).

At the end of gastrulation and just before the beginning of the formation of the first somite, the optic primordia, the head, and the Kupffer's vesicle were observed. With the formation of the ninth somite, the otic capsules appeared behind the optic cups ( $52 \mathrm{hpf}$ ). Then, at $63 \mathrm{hpf} 17$ somites were clearly recognized and the ocular lens development began.

At $95 \mathrm{hpf}$ the original multiple oil droplets completely coalesced in a single large drop. In a dorsal view, this oil drop can be seen located just anterior to the head. Two hours later, well developed optic and otic capsules can be seen ( $97 \mathrm{hpf}$; Fig. 1E). At $131 \mathrm{hpf}$, the heart was actively bombing and the tail coiled. One day after ( $147 \mathrm{hpf}$ ) some chromatophores could be seen on the dorsal part of the body, as well as the ocular pigmentation.

Table 2. Total length (TL) and days post hatching (DPH) corresponding to developmental events of free embryos and larvae reared at MixPT.

\begin{tabular}{lcc}
\hline \multicolumn{1}{c}{ Event } & $\begin{array}{c}\text { TL (range, } \\
\mathrm{mm})\end{array}$ & DPH \\
\hline Hatching & $6.5-7.6$ & 0 \\
Exogenous feeding & $7.4-8.2$ & 2 \\
First rays fin caudal & $8.3-8.9$ & 7 \\
Notochord flexion and the rays became segmented & $9.1-10.4$ & $7-21$ \\
Caudal fin rays complete & $11.1-11.7$ & $14-28$ \\
First dorsal fin rays & 12.6 & $14-28$ \\
Forked homocercal caudal fin & $13.9-15.0$ & $21-35$ \\
Caudal fin rays bifurcated & $18.4-19.4$ & $28-49$ \\
Fin-fold absorption & $20.1-23.0$ & $42-56$ \\
\hline
\end{tabular}

Between 170 and $220 \mathrm{hpf}$ the pectorals fins, bile vesicle, and the swim bladder could be clearly observed (Fig. 1F).

Finally, hatching ocurred at $270 \mathrm{hpf}$. This point represents the time at which $50 \%$ of the larvae have already hatched. The free embryos $(6.5-7.6 \mathrm{~mm})$ presented a characteristic median finfold, big otoliths, a conspicuous notochord, and a single ovoid oil droplet (Fig. 1G).

A summary of the developmental stages of pejerrey embryos is shown in the Table 1.

\section{Larval development}

Total length and days post-hatching (dph) of free embryos and larvae corresponding to ontogenetic events are shown in Table 2.

Beginning of exogenous feeding: At 2 dph (7.4-8.2 mm), the larvae showed active movements and swan in the superficial layer of the water. The exogenous feeding on Artemia nauplii started.

Finfold development: The caudal fin development was characterized by a restructuration from a rounded primary structure to a definitive forked homocercal shape (Fig. 2). During this transition, the first fin rays appeared on the ventral portion of the caudal fin (8.3-8.9 mm, 7dph). At this moment, the larvae still presented a straight notochord (Fig. 2A). With the beginning of the formation of the first caudal rays, the notochord flexion started (9.1-10.4 mm, 7-21 dph). This movement resulted in a ray alignment with the antero-posterior axis (Fig. $2 \mathrm{~B} ; 2 \mathrm{C})$. At this moment the medial-fin-fold reabsorption started. Finally, the caudal fin acquired the definitive forked homocercal structure (13.9-15.0 mm, 21-35 dph, Fig. 2D). Then, the bifurcation of the central fin rays in the sixth ray's segment began (Fig. 2E). At this moment (20.1-23.0 mm, 42-56 dph), the original fin-fold was almost completely reabsorpted. A remnant fin-fold could be observed between the anus and the anal fin (Fig. 2F), and the body shape acquires the juvenile conformation (Fig. 2G). 



Fig. 2. Fin fold reabsorption during larvae-juvenile transition. A) The characteristic lobulated caudal fin showing the first fin rays (arrowhead) and the straight notochord (arrow); B) The second segment appeared (arrowhead) and the ray started to be aligned with the rostro-caudal axis (arrow); C) The ray aligned with the rostro-caudal axis (arrow); D) The forked homocercal caudal fin; E) Bifurcation of the central fin rays (arrowhead); F) The remnant fin-fold between the anus and the anal fin; G) The body shape acquires the adult conformation. $\mathbf{A}-\mathbf{F}$, bar $=0.5 \mathrm{~mm} ; \mathbf{G}=1 \mathrm{~mm}$. 
Effects of temperature on growth, condition, and meristic characters

The quantitative characterization of the larval development was achieved during 77 days at FPT, 63 days at MixPT and 56 days at MPT in order to reach approximately the same size. All, $\log$ TL (ANCOVA, N = 291, $\mathrm{P}<0.001$ ), $\log \mathrm{BW}$ (ANCOVA, $\mathrm{N}=291, \mathrm{P}<0.001$ ), and CF (ANCOVA, $\mathrm{N}=291$, $\mathrm{P}$ $<0.001)$ differed significantly between temperatures, considering time as a significant co-variable (ANCOVA, $\mathrm{N}=$ $287, \mathrm{P}<0.001$ ) and being the larvae longer, heavier, and more robust at higher temperatures (Fig. 3A-C, Table 3). It is interesting to note that considering size instead time as the independent variable, body size explains the Condition Factor (a measure of body shape) with a $\mathrm{F}$ value of co-variable changing from 383 (co-variable $=$ Time) to 443 (co-variable $=$ Body size), i.e. the degree of development can be directly related to size irrespective of temperature better than time (Fig. 3D, Table 3).

Although less conspicuous, the relationship of $\operatorname{logBW}$ versus $\log \mathrm{TL}$ also differed significantly between developing temperatures (ANCOVA, $\mathrm{N}=287, \mathrm{P}<0.001$ ), with a common slope slightly but significantly higher than $3(95 \%$
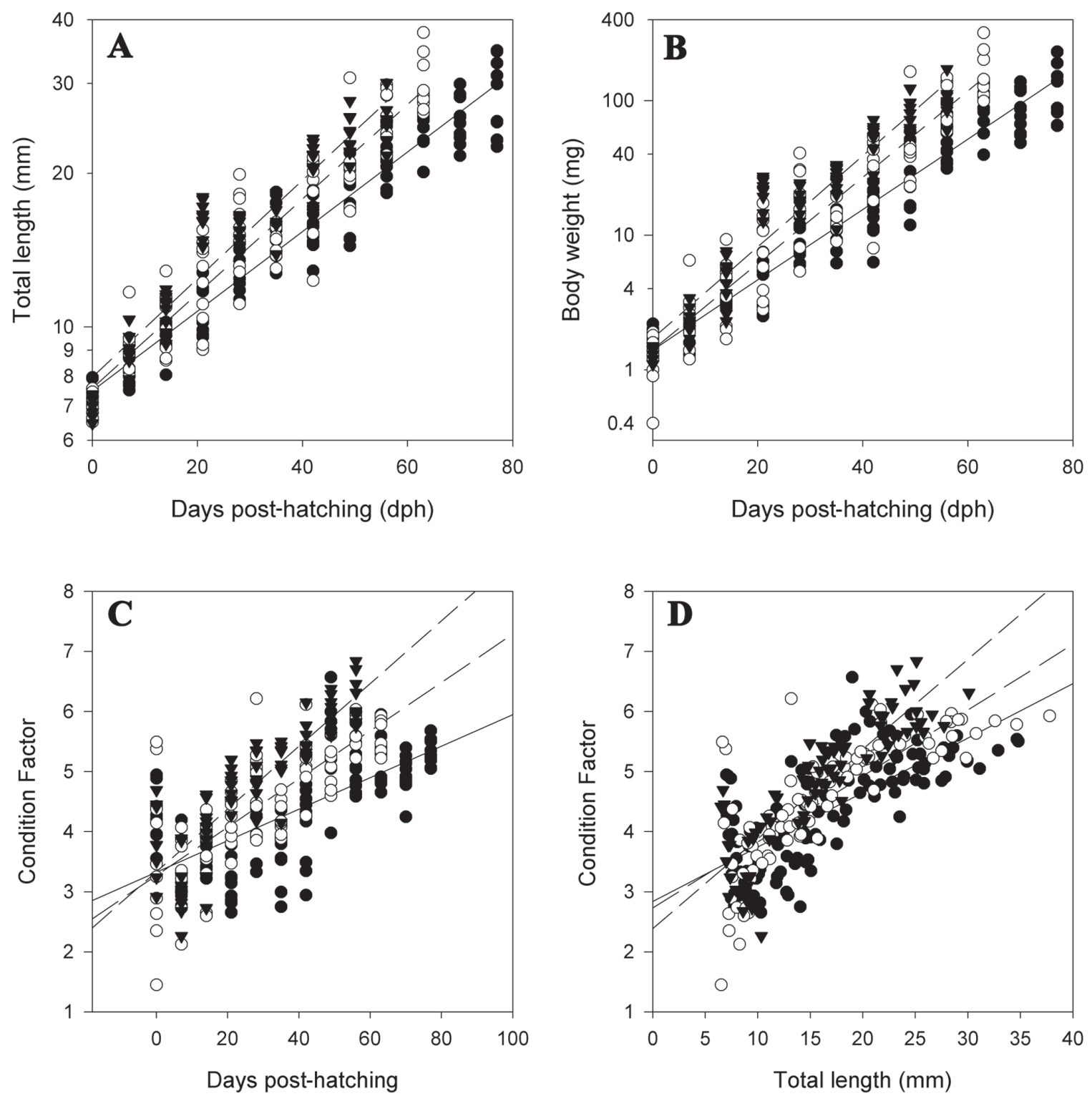

Fig. 3. Total length (A), body weight (B), both in logarithmic scale, and Condition Factor $(\mathbf{C})$ in relation to days post hatching (dph) and water temperature. Female producing temperature (FPT, filled circles and solid line), mixed-sex producing temperature (MixPT, empty circles and long dashed line), and male producing temperature (MPT, triangles and medium size dashed line). Note that when Condition Factor is considered as a function of Total length (D) dispersion diminishes. Lineal regression lines are indicated in order to show the tendency. Regression coefficients and $\mathrm{r}^{2}$ are indicated in Table 3. 
Table 3. Regression coefficients $(Y=a+b . X)$, temperatures $\left(T^{\circ} C\right)$ and $r^{2}$ of the equations fitted in Fig. 3 and 4.

\begin{tabular}{|c|c|c|c|c|c|}
\hline $\mathrm{Y}=$ & $\mathrm{a}$ & $+b$ & $\mathrm{X}$ & $\mathrm{T}^{\circ} \mathrm{C}$ & $\mathrm{r}^{2}$ \\
\hline \multirow{3}{*}{ log Total length (mm) } & 0.8750125826 & $7.806587936 \mathrm{e}-3$ & \multirow{3}{*}{ Days post hatching (dph) } & 17 & 0.9362491701 \\
\hline & 0.8800653739 & $9.270223130 \mathrm{e}-3$ & & 24 & 0.8932340519 \\
\hline & 0.9019366886 & $9.644828454 \mathrm{e}-3$ & & 29 & 0.9081459834 \\
\hline \multirow{3}{*}{ log Body weight (mg) } & 0.1487252087 & 0.0261069603 & \multirow{3}{*}{ Days post hatching (dph) } & 17 & 0.9283523265 \\
\hline & 0.150164111 & 0.0320462293 & & 24 & 0.8852029371 \\
\hline & 0.2352059927 & 0.0339170351 & & 29 & 0.9137481102 \\
\hline \multirow{3}{*}{ Condition Factor } & $3.328951688 \mathrm{e}-3$ & $2.622077894 \mathrm{e}-5$ & \multirow{3}{*}{ Days post hatching (dph) } & 17 & 0.4808749279 \\
\hline & $3.274492228 \mathrm{e}-3$ & $4.012380058 \mathrm{e}-5$ & & 24 & 0.611313859 \\
\hline & $3.338880945 \mathrm{e}-3$ & $5.212077784 \mathrm{e}-5$ & & 29 & 0.7722985899 \\
\hline \multirow{3}{*}{ Condition Factor } & $2.837346867 \mathrm{e}-3$ & $9.075799020 \mathrm{e}-5$ & \multirow{3}{*}{ Total length (mm) } & 17 & 0.5187828299 \\
\hline & $2.730902885 \mathrm{e}-3$ & $1.097818274 \mathrm{e}-4$ & & 24 & 0.6248020549 \\
\hline & $2.387184154 \mathrm{e}-3$ & $1.495034898 \mathrm{e}-4$ & & 29 & 0.7552203085 \\
\hline \multirow{3}{*}{ Number of segments } & -0.7320136925 & 0.1278166394 & \multirow{3}{*}{ Days post hatching (dph) } & 17 & 0.9073954999 \\
\hline & -0.0554012424 & 0.1374750193 & & 24 & 0.8200485421 \\
\hline & 0.2411666159 & 0.1454244811 & & 29 & 0.9294294466 \\
\hline
\end{tabular}

Confidence Interval $=3.375,3.458)$. In the same way, the number of caudal fin segments showed a significant dependence with temperature, in addition to the significant co-variation with time and total length (ANCOVA, $\mathrm{N}=234, \mathrm{P}$ $<0.001$, Fig. 4, Table 3).

Fish reared under different temperatures were also discriminated based on their body shape (DA applied on unstandardized residuals, $\mathrm{N}=287, \mathrm{P}<0.001$; Fig. 5). During the rearing period, clear differences among larvae were observed in the rate of fin fold restructuration (Fig. 6).

\section{Discussion}

Just like all teleosts (Kunz, 2004), pejerrey showed a discoidal meroblastic cleavage pattern, where the large yolk volume restricts cell divisions to a small area at the animal pole. Twenty two developmental stages could be recognized during the embryogenesis which can be used to compare to closely

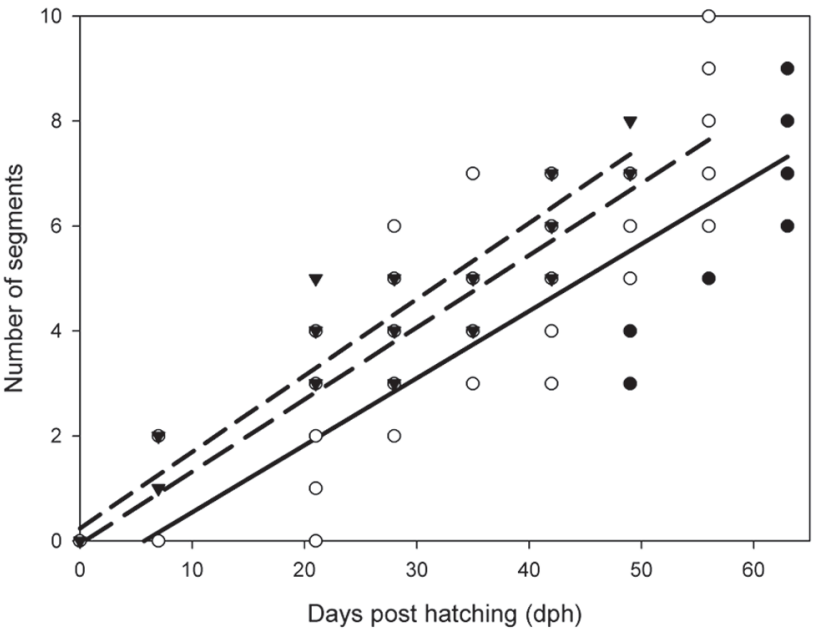

Fig. 4. Number of caudal fin segments in relation to days post hatching (dph) and water temperature; $17^{\circ} \mathrm{C}$ (filled circles and solid line), $24^{\circ} \mathrm{C}$ (empty circles and long dash line), and $29^{\circ} \mathrm{C}$ (triangles and medium dash line). Regression coefficients and $\mathrm{r}^{2}$ are indicated in Table 3. related species. In this way, some similarities were observed when compared to medaka's, Oryzias latipes, embryogenesis (Iwamatsu, 2004). For example the array of 4 central and 12 peripheral cells at the fourth cleavage event, the formation of embryonic shield at $25 \%$ of epiboly, and the development of optic primordial before the somitogenesis started. In addition, some similarities were observed when compared to other Atheriniformes, which embryos shared the presence of a single row of melanophores over the dorsal portion of the body and a short preanal length, less than $40 \%$ of standard length until the notochord flexion (White et al., 1984). There were also some ontogenetic characters: presence of adherent filaments, oil droplets coalescing and position of developing heart; shared with other Atheriniformes, Beloniformes, and Cyprinodontiformes. These morphological characteristics may support the concept of Atherinomorpha as a monophyletic group (Rosen, 1964; Dyer, 2006; Setiamarga et al., 2008).

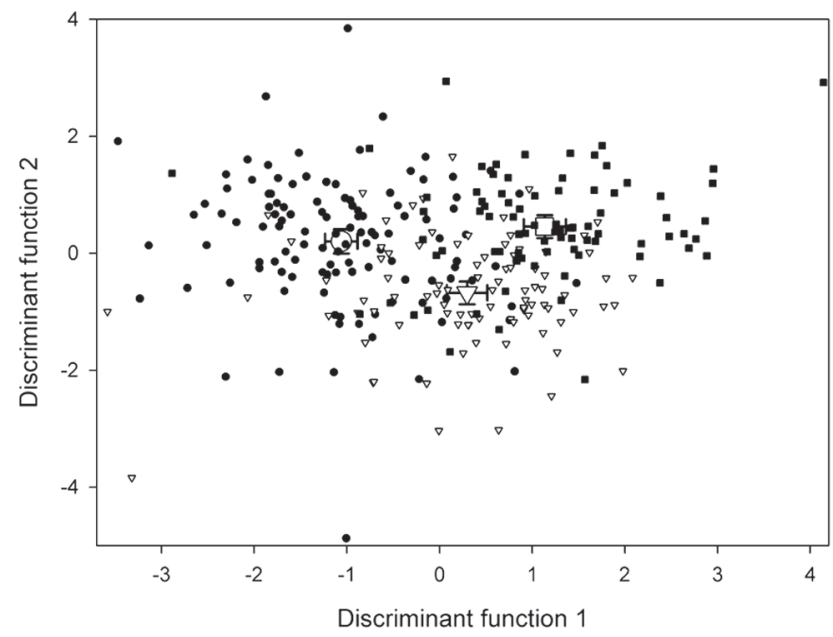

Fig. 5. Body shape (DA applied on un-standardized residuals, $\mathrm{N}=287, \mathrm{P}<0.001$ ). Discriminant function 2 versus discriminant function 1. Rearing temperature is indicated as black circles (FPT), triangles (MixPT) and black squares (MTP). Means and $95 \%$ confidence intervals correspond to FPT (circle), MixPT (triangle), and MTP (square). 

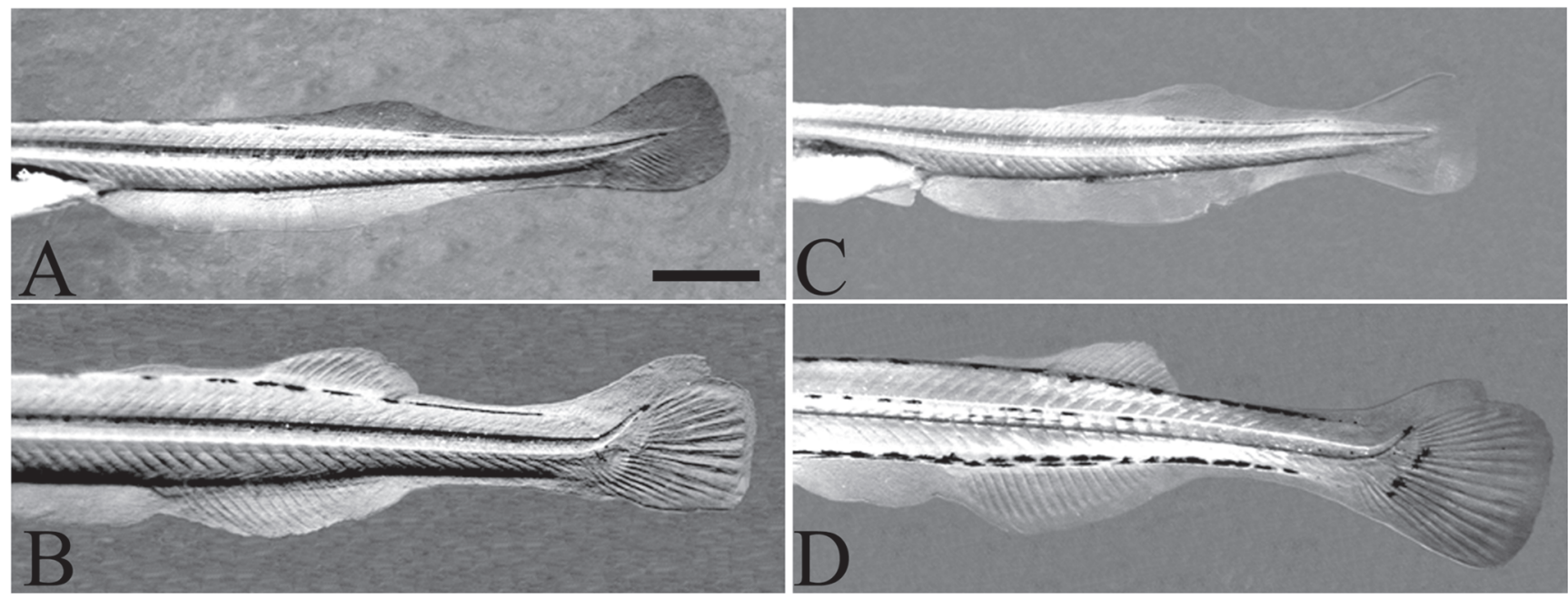

Fig. 6. Differences in the rate of fin fold restructuration among larvae. A-B) same age, same temperature and different finfold stages; C-D) same age, different temperature and different finfold stage; B-D) different temperature, same age and same finfold stage. A) $24^{\circ} \mathrm{C}, 14 \mathrm{dph}, \mathrm{TL}=9.1 \mathrm{~mm}$; B) $24^{\circ} \mathrm{C} 14 \mathrm{dph}, \mathrm{TL}=11.7 \mathrm{~mm}$; C) $17^{\circ} \mathrm{C} 14 \mathrm{dph}, \mathrm{TL}=8.1 \mathrm{~mm}$; D) $29^{\circ} \mathrm{C} 14 \mathrm{dph}, \mathrm{TL}=11.1 \mathrm{~mm}$. Bar $=1 \mathrm{~cm}$.

Metamorphosis, the transition from larvae to juveniles, has great importance as it displays development programs under selective pressures operating during free life. In pejerrey, one informative metamorphic change was fin development and, especially, the caudal fin. Like most teleost fish (Kendall et al., 1984), pejerrey larvae possess at hatching a median-fin-fold from which the odd fins (anal, caudal, first and second dorsal) develop. Fin growth takes place by sequential addition of new ray segments to the distal end of each ray (Santamaria \& Becerra, 1991). During the caudal fin transition from a lobulated to a homocercal structure, these rays should change their growth in order to develop longer dorsal and ventral and shorter central rays. This could be accomplished in two ways: a) all rays increase segment number synchronously but there is a differentially higher rate of rays growing of dorsal and ventral fin rays over central fin rays or b) through an asynchronycal addition of segments, skipping cycles of segment addition in the central rays (Goldsmith et al., 2003; 2006). In pejerrey larvae, all caudal rays had the same number of segments implying that the caudal fin shape is achieved by differential growth rate.

During fin fold reabsorption not only the caudal fin underwent restructuration but also did the anal, first and second dorsal fins. Fin fold reabsorption was the last clear morphologic change observed and then it could be considered as the end of the metamorphic process in pejerrey (from 42 to $56 \mathrm{dph} ; 20.1$ to $23 \mathrm{~mm} \mathrm{TL}$ ).

In this species, as in any ectotherm organism, larval growth rate, both in length and weight, was affected by temperature (Angilletta et al., 2004). Larvae of the same age were longer and heavier and had more caudal fin-ray segments when they were raised at higher temperatures. Temperature also affected the moment of definitive caudal fin shape acquisition. It must be noted that, in agreement with Fuiman et al. (1998), this thermal dependence of a time related processes diminished when the developmental changes were considered in terms of body length. Thus, size could be useful indicators of the degree of development.

In pejerrey, male producing temperature, $29^{\circ} \mathrm{C}$, is close to the lethal temperature $\left(32^{\circ} \mathrm{C}\right)$ reported for juveniles, it is higher than rearing temperatures usually considered appropriate for this species (Gómez et al., 2007; Somoza et al., 2008), and can induce partial (numerically or temporarily) or even permanent sterility in larvae, juveniles and adults of both sexes in pejerrey (Strüssmann et al., 2010). Even when deformities were not observed at $29^{\circ} \mathrm{C}$ in this work, they were reported by Strüssmann et al. (1997) in similar experiments. However, it is important to know that growth at MPT was achieved with an allometric index greater than 3 indicating that the condition in larvae rearing on this temperature range is physiologically suitable.

In summary, we provided a brief morphological and quantitative description of embryonic and larval period of $O$. bonariensis and showed clear effects of temperature on larval growth and condition. The present data showed that, in pejerrey, the degree of development can be inferred from size, as already stated in other fish species (Sæle \& Pittman, 2010). The juvenile phenotype is acquired when the fin fold is reabsorbed and the caudal fin acquires the definitive forked homocercal structure. These data will allow performing new studies taking the present development description as a reference point in the framework of studies related to TSD and chronologies of sexual determination and differentiation.

\section{Acknowledgements}

We would like to acknowledge the following institutions for granting present projects: Universidad Nacional del Comahue, CONICET and FONCYT (PICT 16-38026 and 2008- 
1383 to G.M.S.). We would also like to acknowledge Marcia Giambiaggi de Marval for help in translation and Ricardo S. Hattori for fruitful discussions.

\section{Literature Cited}

Adriaens, D. \& W. Verraes. 2002. An empirical approach to study the relation between ontogeny, size and age using geometric morphometrics. Pp. 293-324. In: Aerts, P., K. D'Août, A. Herrel \& R. Van Damme (Eds). Topics in functional and ecological vertebrate morphology. Maastricht, Shaker Publishing, 372p.

Al Hazzaa, R. \& A. Hussein. 2007. Larval development of himri, Barbus luteus (Cyprinidae: Cypriniformes) reared in the laboratory. Turkish Journal of Zoology, 31: 27-33.

Angilletta, M. J. Jr., T. D. Steury \& M. W. Sears. 2004. Temperature, growth rate, and body size in ectotherms: fitting pieces of a life-history puzzle. Integrative and Comparative Biology, 44: 498-509.

Balon, E. K. 1990. Epigenesis of an epigeneticist: the development of some alternative concepts on the early ontogeny and evolution of fishes. Guelph Ichthyology Reviews, 1: 1-48.

Balon, E. K. 1999. Alternative ways to become a juvenile or a definitive phenotype (and on some persisting linguistic offenses). Environmental Biology of Fishes, 56: 17-38.

Balon, E. K. 2001. Saltatory ontogeny and life-history model: neglected processes and patterns of evolution. Journal of Bioeconomics, 3: 1-26.

Berlinsky, D. L., J. C. Taylor, R. A. Howell \& T. M. Bradley. 2004. The effects of temperature and salinity on early life stages of black sea bass Centropristis striata. Journal of the World Aquaculture Society, 35: 335-344.

Blaxter, J. H. S. 1988. Pattern and variety in development. Pp. 148. In: Hoar, W. S. \& D. J. Randall (Eds). Fish Physiology Vol. 11 (Part A). New York, Academic Press, 545p.

Blaxter, J. H. S. 1992. The effect of temperature on larval fishes. Netherlands Journal of Zoology, 42: 336-357.

Chambers, R. C. \& W. C. Leggett. 1987. Size and age at metamorphosis in marine fishes: An analysis of lab-reared winter flounder Pseudopleuronectes americanus with a review of variation in other species. Canadian Journal of Fisheries and Aquatic Sciences, 44: 1936-1947.

Copp, G. H., V. Kovác \& K. Hensel. 1999. When do fishes become juveniles? Dordrecht, Kluwer Academic Publishers, 289p.

Dyer, B. S. 2006. Systematic revision of the South American silversides (Teleostei, Atheriniformes). Biocell, 30: 69-88.

Fernandino, J. I., R. S. Hattori, H. Kimura, C. A. Strüssmann \& G. M. Somoza. 2008a. Expression profile and estrogenic regulation of anti-müllerian hormone during gonadal development in pejerrey Odontesthes bonariensis, a teleost fish with strong temperature-dependent sex determination. Developmental Dynamics, 237: 3192-3199.

Fernandino, J. I., R. S. Hattori, T. Shinoda, H. Kimura, P. H. StroblMazzulla \& C. A. Strüssmann. 2008b. Dimorphic expression of dmrt1 and cyp19a1 (ovarian aromatase) during early gonadal development in pejerrey, Odontesthes bonariensis. Sexual Development, 2: 316-324.

Fuiman, L. A., K. R. Poling \& D. M. Higgs. 1998. Quantifying developmental progress for comparative studies of larval fishes. Copeia, 3: 602-611.

Fujimura, K. \& N. Okada. 2007. Development of the embryo, larva and early juvenile of Nile tilapia Oreochromis niloticus (Pisces:
Cichlidae). Developmental staging system. Development Growth and Differentiation, 49: 301-324.

Goldsmith, M. I., S. Fisher, R. Waterman \& S. L. Johnson. 2003. Saltatory control of isometric growth in the zebrafish caudal fin is disrupted in long fin and rapunzel mutants. Developmental Biology, 259: 303-317.

Goldsmith, M. I., M. K. Iovine, T. O’Reilly-Pol \& S. L. Johnson. 2006. A developmental transition in growth control during zebrafish caudal fin development. Developmental Biology of Fish, 296: 450-457.

Gómez, S. E., R. C. Menni, J. Gonzalez Naya \& L. Ramirez. 2007. The physical-chemical habitat of the Buenos Aires pejerrey, Odontesthes bonariensis (Teleostei, Atherinopsidae), with a proposal of a water quality index. Environmental Biology of Fishes, 78: 161-171.

Gozlan, R. E., G. H. Copp \& J. Tourenq. 1999. Early development of the sofie, Chondrostoma toxostoma. Environmental Biology of Fishes, 56: 67-77.

Hensel, K. 1999. To be a juvenile and not to be a larva: an attempt to synthesize. Environmental Biology of Fishes, 56: 277-280.

Ito, L. S., M. Yamashita, F. Takashima \& C. A. Strüssmann. 2005. Dynamics and histological characteristics of gonadal sex differentiation in pejerrey (Odontesthes bonariensis) at feminizing and masculinizing temperatures. Journal of Experimental Zoology, 303A: 504-514.

Iwamatsu, T. 2004. Stages of normal development in the medaka Oryzias latipes. Mechanisms of Development, 121: 605-618.

Karube, M., J. I. Fernandino, P. H. Strobl-Mazzulla, C. A. Strüssmann, G. Yoshizaki, G. M. Somoza \& R. Patiño. 2007. Characterization and expression profile of the ovarian cytochrome p-450 aromatase (cyp19a1) gene during the thermolabile sex determination period in pejerrey, Odontesthes bonariensis. Journal of Experimental Zoology, 307A: 625-636.

Kawakami, Y., J. Nozaki, M. Seoka, H. Kumai \& H. Ohta. 2008. Characterization of thyroid hormones and thyroid hormone receptors during the early development of Pacific bluefin tuna (Thunnus orientalis). General and Comparative Endocrinology, 155: 597-606.

Kendall, A. W., E. H. Ahlstrom \& H. G. Moser. 1984. Early life history stages of fishes and their characters. In: Ahlstrom. E., B. Sandknop, H. Sumida, H. Moser (Eds). Pp 11-22. Ontogeny and Systematic of Fishes. An International Symposium Dedicated to the Memory of Elbert Halvor. University of Kansas. Lawrence, 760p.

Kováè, V. \& G. H. Copp. 1999. Prelude: looking at early development in fishes. Environmental Biology of Fishes, 56: 7-14.

Kunz, Y. W. 2004. Developmental Biology of Teleost Fishes. Kluwer Academic Publishers. Dordrecht, 652p.

López-Olmeda, J. F. \& F. J. Sánchez-Vázquez. 2010. Thermal biology of zebrafish (Danio rerio). Journal of Thermal Biology, 36: 91-104.

Martell, D. J., J. D. Kieffer \& E. A. Trippel. 2005. Effects of temperature during early life history on embryonic and larval development and growth in haddock. Journal of Fish Biology, 66: 1558-1575.

McElman, J. F. \& E. K. Balon. 1979. Early ontogeny of walleye, Stizostedion vitreum, with steps of saltatory development. Environmental Biology of Fishes, 4: 309-348.

Minoprio, J. L. 1944. Consideraciones sobre el desarrollo embrionario del pejerrey. Acta Zoologica Lilloana, 2: 9-25.

Muñiz Saavedra, J. \& G. Piacentino. 1991. Estudio del desarrollo 
ontogenético de Odontesthes bonariensis (Cuvier y Valenciennes, 1835). Medio Ambiente, 11: 61-68.

Murphy, B. F., J. M. Leis \& K. D. Kavanagh. 2007. Larval development of the Ambon damselfish Pomacentrus amboinensis, with a summary of pomacentrid development. Journal of Fish Biology, 71: 569-584.

Pepin, P. 1991. Effect of temperature and size on development, mortality, and survival rates of the pelagic early life history stages of marine fish. Canadian Journal of Fisheries and Aquatic Sciences, 48: 503-518.

Potthoff, T. 1984. Clearing and staining techniques. Pp. 35-37. In: Ahlstrom. E., B. Sandknop, H. Sumida, H. Moser (Eds). Ontogeny and systematic of fishes. An international symposium dedicated to the memory of Elbert Halvor Ahlstrom. University of Kansas. Lawrence, 760p.

Rosen, D. E. 1964. The relationships and taxonomic position of the halfbeaks, killifishes, silversides, and their relatives. Bulletin of the American Museum of Natural History, 127: 217-268.

Sæle, Ø.\& K. A. Pittman. 2010. Looking closer at the determining of a phenotype? Compare by stages or size, not age. Journal of Applied Ichthyology, 26: 294-297.

Santamaria, J. A. \& J. Becerra. 1991. Tail fin regeneration in teleosts: cell-extracellular matrix interaction in blastemal differentiation. Journal of Anatomy, 176: 9-21.

Setiamarga, D. H. E., M. Miya, Y. Yamanoue, K. Mabuchi, T. K. Satoh, J. G. Inoue \& M. Nishida. 2008. Interrelationships of Atherinomorpha (medakas, flyingfishes, killifishes, silversides, and their relatives): The first evidence based on whole mitogenome sequences. Molecular Phylogenetics and Evolution, 49: 598-605.

Somoza, G. M., L. A. Miranda, G. E. Berasain, D. Colautti, M. Remes Lenicov \& C. A. Strüssmann. 2008. Historical aspects, current status, and prospects of pejerrey aquaculture in South America. Aquaculture Research, 39: 784-793.

Strüssmann, C. A., D. A. Conover, G. M. Somoza \& L. A. Miranda. 2010. Implications of climate change for the reproductive capacity and survival of New World silversides (family Atherinopsidae). Journal of Fish Biology, 77: 1818-1834.
Strüssmann, C. A., S. Moriyama, E. F. Hanke, J. C. Calsina Cota \& F. Takashima. 1996a. Evidence of thermolabile sex determination in pejerrey, Odontesthes bonariensis. Journal of Fish Biology, 48: 643-651.

Strüssmann, C. A. \& R. Patiño. 1995. Temperature manipulation of sex differentiation in fish. Pp. 153-157. In: Goetz, F \& P. Thomas (Eds). Proceedings of the Fifth International Symposium on the Reproductive Physiology of Fish. University of Texas. Austin, 389p.

Strüssmann, C. A., T. Saito, M. Usui, H. Yamada \& F. Takashima. 1997. Thermal thresholds and critical period of thermolabile sex determination in two atherinid fishes, Odontesthes bonariensis and Patagonina hatcheri. Journal of Experimental Zoology, 278: 167-177.

Strüssmann, C. A., F. Takashima \& K. Toda. 1996b. Sex differentiation and hormonal feminization in pejerrey Odontesthes bonariensis. Aquaculture, 139: 31-45.

Webb, J. F. 1999. Larvae in fish development and evolution. Pp. 109-158. In: B.K. Hall \& M.H. Wake (Eds). The origin and evolution of larval forms. New York, Academic Press, 448p.

White, H., J. Lavenberg \& C. McGowen. 1984. Atheriniformes: Development and Relationships. pp 355-362. In: Ahlstrom, E., B. Sandknop, H. Sumida, H. Moser (Eds). Ontogeny and Systematic of Fishes. An International Symposium Dedicated to the Memory of Elbert Halvor Ahlstrom. University of Kansas. Lawrence, 760p.

Youson, J. H. 1988. First metamorphosis. Pp. 135-184. In: Hoar, W.S. \& D.J. Randall (Eds). Fish Physiology, Vol. 11 (Part B). New York, Academic Press, 436p.

Youson, J. H. 2003. The impact of environmental and hormonal cues on the evolution of fish metamorphosis. Pp. 239-277. In: Hall, B. K. \& R. D. Pearson (Eds). Environment, Development, and Evolution: Toward a Synthesis. Cambridge, MIT Press, 328p.

Submitted May 9, 2011

Accepted July 17, 2011

Published December 26, 2011 